\title{
PENERAPAN COOPERATIVE LEARNING TIPE STAD DAN SNOWBALL DRILLING UNTUK MENINGKATKAN KEAKTIFAN DAN PRESTASI BELAJAR IPS
}

\author{
Ika Oktavianti, Santoso \\ Universitas Muria Kudus
}

\begin{abstract}
ABSTRAK
Tujuan penelitian ini adalah untuk menganalisis seberapa besar peningkatan keaktifan dan prestasi belajar IPS setelah diterapkannya model pembelajaran cooperative learning tipe STAD dan Snowball Drilling berbasis bimbingan dan berbantuan media massa. Penelitian ini dilaksanakan di SD Tumpangkrasak 2 Kecamatan Jati Kabupaten Kudus dengan subyek penelitian siswa kelas III dan fokus penelitian pada keaktifan dan prestasi belajar IPS. Data dikumpulkan dengan teknik observasi partisipasif, pengukuran hasil tes dan dokumentasi. Hasil penelitian menunjukkan bahwa presentase keaktifan siswa pada siklus I yaitu 74,5\% dengan kriteria baik mengalami peningkatan pada siklus II yaitu $77,5 \%$. Adapun persentase ketuntasan prestasi belajar pada siklus I naik menjadi $66 \%$, dan pada siklus II naik lagi menjadi $83,33 \%$. Simpulan dari penelitian ini adalah penerapan model pembelajaran cooperative learning tipe STAD dan Snowball Drilling elas III SD Tumpangkrasak 2 Kudus dapat meningkatkan keaktifan dan prestasi belajar IPS.
\end{abstract}

Kata Kunci: STAD, Snowball Drilling, Keaktifan, Prestasi Belajar IPS

\section{PENDAHULUAN}

Pendidikan IPS sebagai salah satu mata pelajaran yang bertujuan meningkatkan dan menumbuhkan pengetahuan, kesadaran dan sikap sebagai warga negara yang bertanggung jawab, menuntut pengelolaan pembelajaran secara dinamis dengan mendekatkan siswa kepada realitas objektif kehidupannya. Permasalahan yang terjadi selama ini, pembelajaran IPS dinilai tidak berhasil mencapai tujuan pembelajaran yang diharapkan.

Dalam realitas pembelajaran IPS, persoalan manusia dan sosial kemanusian tak banyak disentuh. Bahkan, dalam proses pembelajaran, guru IPS dan siswa hanya melakukannya sekadarnya. Tak ada inovasi-inovasi pembelajaran yang konkret yang bisa membuat pendidikan IPS mencapai tujuan. Bahkan selama ini, pembelajaran IPS dianggap sebagai suatu mata pelajaran yang membosankan, monoton, kurang menyenangkan, terlalu banyak hafalan, kurang variatif, dan berbagai keluhan lainnya. Hal ini disebabkan proses pembelajaran IPS, guru IPS kurang optimal baik di dalam memanfaatkan maupun memberdayakan sumber pembelajaran, karena dalam proses pembelajaran IPS cenderung masih berpusat pada guru, berpusat pada buku, dan monomedia.

Permasalahan yang muncul dari kondisi pembelajaran IPS tersebut, sebagian siswa menganggap mata pelajaran IPS sebagai mata pelajaran yang sulit dipahami sehingga siswa cenderung merasa bosan, jenuh dan malas untuk belajar, siswa kurang termotivasi karena menganggap mata pelajaran IPS merupakan mata pelajaran yang membutuhkan pemahaman konsep yang luas. Aktivitas siswa yang rendah ini dapat mempengaruhi hasil belajar siswa, seperti yang terjadi pada siswa Kelas III SD Tumpangkrasak 2 Kudus.

Hasil observasi awal menunjukkan bahwa kurang efektifnya pembelajaran IPS, dimana ketika pembelajaran banyak siswa yang berbicara sendiri serta adanya beberapa 
anak yang kurang berkonsentrasi dengan materi yang diajarkan. Hasil observasi awal juga menunjukkan bahwa siswa kurang aktif dalam pembelajaran IPS sehingga prestasi belajar sebagian siswa kurang memenuhi KKM yaitu minimal 65 .

Permasalahan pembelajaran IPS yang terjadi perlu segera dilakukan tindakan pemecahan masalah. Salah satu upaya yang dapat dilakukan adalah mengupayakan pengembangan strategi pembelajaran yang tepat, menarik dan efektif sehingga dapat meningkatkan keterampilan guru, aktivitas siswa serta hasil belajar siswa yaitu dengan jalan mengubah paradigma guru dari pembelajaran konvensional ke pembelajaran PAIKEM.

Untuk memujudkan pembelajaran PAIKEM tersebut, tim peneliti menggunakan salah satu strategi pembelajaran yang dapat dijadikan alternatif yaitu Cooperative Learning. Pembelajaran kooperatif memiliki dampak positif terhadap siswa yang rendah prestasi belajarnya dan dapat membantu membangun kepercayaan diri terhadap kemampuan berfikir kritis dalam memahami konsep IPS.

Pendidikan tidak mungkin dapat terselenggara dengan baik bilamana para tenaga kependidikan maupun para peserta didik tidak didukung oleh sumber belajar yang diperlukan untuk penyelenggaraan kegiatan belajar mengajar yang bersangkutan. Sementara itu, seiring dengan pesatnya perkembangan IPTEK, informasi dan komunikasi membawa perubahan bergesernya peranan guru Ilmu Pengetahuan Sosial sebagai penyampai ilmu pengetahuan dan informasi. Ia tidak bisa lagi berperan sebagai satusatunya sumber informasi bagi kegiatan pembelajaran para siswanya. Dari hasil observasi juga menunjukkan bahwa guru kurang menggunakan sumber belajar terutama media pembelajaran.

Sudah saatnya pengajaran IPS tidak dibiarkan hampa dengan media. Sebab diyakini bahwa dengan memiliki media pembelajaran yang baik setidaknya dapat menghapuskan image negatif terhadap pengajaran IPS. Siswa dapat memperoleh informasi dari berbagai sumber terutama dari media massa, baik televisi, radio dan internet (media elektronik), surat kabar dan majalah (media cetak).

Media massa sangat berpengaruh di dalam pendidikan IPS karena IPS merupakan synthetic science dimana konsep, generalisasi, dan temuan-temuan penelitian ditentukan atau diobservasi setelah fakta terjadi. Informasi faktual tentang kehidupan sosial atau masalah-masalah kontemporer yang terjadi di masyarakat dapat ditemukan dalam liputan media massa, karena media massa diyakini dapat menggambarkan realitas sosial dalam berbagai aspek kehidupan.

Achmad (2004) dalam artikel "Pemanfaatan Internet sebagai Sumber Pembelajaran IPS", media massa dapat menunjang keberhasilan proses pembelajaran IPS melalui tiga cara, yaitu: 1) media massa dapat memperbaiki bagian content dari kurikulum IPS; 2) media massa dapat dijadikan alat pembelajaran yang penting bagi IPS; dan 3) media massa dapat digunakan untuk menolong siswa mempelajari metodologi ilmu-ilmu sosial, khususnya di dalam menentukan dan menginterpretasi fakta-fakta sosial.

Berdasarkan uraian latar belakang di atas, maka tim peneliti mengambil judul "Penerapan Model Pembelajaran Cooperative Learning Tipe STAD Dan Snowball Throwing Berbasis Bimbingan dan Berbantuan Media Massa Untuk Meningkatkan Keaktifan Dan Prestasi Belajar Siswa Pada Mata Pelajaran IPS"

\section{METODE PENELITIAN}

Penelitian tindakan kelas ini dilaksanakan di SD Tumpangkrasak 2 Gugus Wibisono Kecamatan Jati Kabupaten Kudus, dengan subjek dalam penelitian ini adalah siswa Kelas III semester 2 dengan fokus penelitian pada keaktifan dan prestasi belajar siswa dalam pembelajaran IPS. 
Penelitian ini jenis penelitian yang digunakan adalah penelitian tindakan kelas. Menurut Kurt Lewin, prosedur kerja dalam penelitian tindakan kelas terdiri atas empat komponen, yaitu perencanaan (planning), pelaksanaan (acting), pengamatan (observing), dan refleksi (reflecting). Hubungan keempat komponen tersebut dipandang sebagai satu siklus (Depdikbud, 1999).

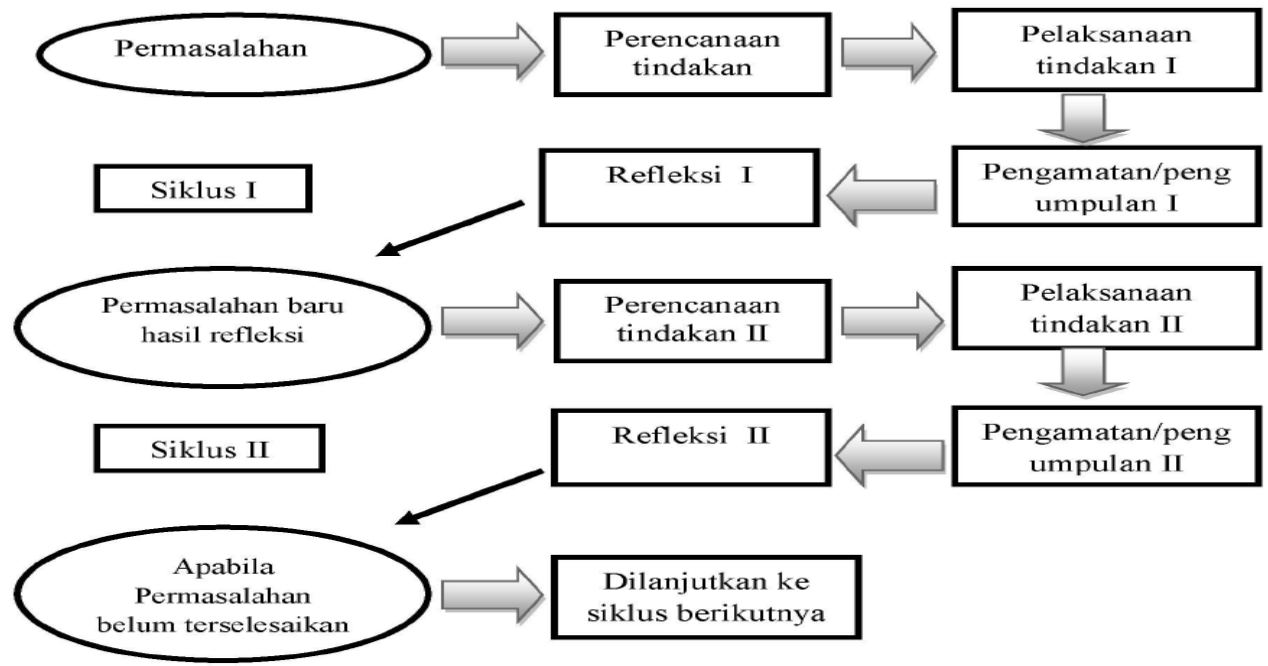

Gambar 1. Alat Pelaksanaan Penelitian Tindakan Kelas

Sumber: Kemmis dan Taggart dalam Suharsimi (2006)

Untuk memperoleh data yang benar dan akurat dalam penelitian ini, maka penulis menggunakan beberapa metode yang antara lain: 1) observasi partisipatif, 2) metode pengukuran hasil tes, 3) metode dokumentasi. Analisis yang digunakan dalam penelitian tindakan kelas ini adalah teknik analisis deskriptif dengan menentukan presentasi ketuntasan belajar dan mean (rata-rata) kelas.

\section{HASIL PENELITIAN DAN PEMBAHASAN}

Student team-achievement divisions merupakan salah satu metode pembelajaran kooperatif yang paling sederhana, dan merupakan model yang paling baik untuk permulaan bagi para guru. Metode ini sangat mudah diadaptasi dan telah digunakan dalam IPS, sains, ilmu pengetahuan sosial, bahasa inggris, dan teknik.

Penelitian yang sudah dilakukan oleh peneliti ternyata membuahkan hasil bahwa adanya peningkatan prestasi belajar dan keaktivan siswa melalui model pembelajaran Cooperative Learning tipe STAD dan Snowball Throwing berbasis bimbingan dengan berbantuan Media Massa. Peningkatan prestasi belajar tersebut terbukti dengan adanya peningkatan tiga ranah belajar siswa, yaitu kognitif, afektif dan psikomotorik. Pandangan ini tertuang dalam Kamus Besar Bahasa Indonesia (2001: 787) menyebutkan prestasi belajar adalah penguasaan pengetahuan atau ketrampilan yang dikembangkan oleh mata pelajaran lazimnya ditunjukkan dengan nilai tes. Pada penerapan STAD, evaluasi pembelajaran dilaksanakan dengan dua cara yaitu penilaian tim dan penilaian individu.

Merekognisi prestasi tim, ada tiga cara macam tingkatan penghargaan yang diberikan di sini. Ketiganya didasarkan pada rata-rata skor tim, sebagai berikut.

Tabel 1 Kriteria rata-rata skor tim

\begin{tabular}{|c|c|}
\hline Kriteria Rata-rata Tim & Penghargaan \\
\hline 15 & Tim baik \\
\hline 16 & Tim sangat baik \\
\hline
\end{tabular}


Sumber: Slavin, 2010: 160

Tim super

Dalam merekognisi prestasi tim, siswa dibentuk menjadi beberapa kelompok agar terjadi ketergantungan positif antar siswa pada kelompok tersebut, sehingga tercipta kerjasama tim untuk menyelesaikan tugas yang diberikan oleh guru. Pemahaman yang dicapai siswapun merata yang kemudian dibuktikan dengan kuis bagi tiap individu, dari kuis inilah guru dapat melihat bagaimana hasil belajar siswa secara personal.

Pada penelitian ini, peneliti sekaligus guru yang menentukan kelompok yaitu dengan diurutkan prestasi sesuai dengan sintak $S T A D$, seperti halnya yang disampaikan oleh Slavin (2010) bahwa Cooperative Learning adalah model pembelajaran yang sesuai untuk melatih siswa bekerjasama dalam sebuah kelompok, dimana LKS tersebut adalah media massa yang terkait dengan materi Jual Beli dan penggunaan Uang sesuai dengan Kebutuhan. Diskusi dalam pembelajaran dilakukan dengan mengerjakan LKS yang sudah disediakan oleh guru Dalam kegiatan diskusi, guru selalu melakukan pendampingan, jika ada kelompok yang merasa belum jelas, baik aturan main diskusi ataupun materi secara berkelompok ataupun individu, guru selalu menjelaskan dengan sabar. Tidak hanya melakukan bimbingan saat proses diskusi. Setelah diskusi guru juga membimbing siswa untuk mempresentasikan hasil kerja kelompok yang kemudian dilanjutkan dengan kuis. Dalam kuis inilah Snowball Throwing dikolaborasikan.

Kuis dilakukan dengan berbantuan bola yang dilempar. Supriyono (2012: 106) juga menjelaskan bahwa dalam penerapan metode Snowball Throwing, peran guru adalah mempersiapkan paket soal-soal pilihan ganda dan menggelindingkan bola salju berupa soal latihan dengan cara menunjuk/mengundi untuk mendapatkan seorang peserta didik yang akan menjawab soal nomor 1. Dalam pelemparan bola tersebut, anggota kelompok mana yang mendapatkan bola. Maka siswa yang mendapatkan bola tersebut harus menjawab pertanyaan dari guru (kuis). Jika siswa tersebut tidak bisa menjawab berarti siswa tersebut harus keluar dari arena permainan. Sebaliknya jika siswa tersebut bisa menjawab, maka siswa tersebut memiliki kekuatan untuk mengeluarkan siswa lain dalam kelompok lain. Sehingga kuis diakhiri jika sudah banyak siswa yang keluar dari arena permainan dan terlihat salah satu kelompok masih memiliki anggota yang masih bertahan. Maka itulah kelompok yang menang. Berikut hasil penelitian terkait kemajuan individu dan kelompok dalam kuis STAD dikolaborasikan dengan Snowball Throwing dapat dilihat dalam tabel 5.2.

\begin{tabular}{|c|c|c|c|c|c|c|}
\hline Klp. & $\begin{array}{c}\text { Anggota } \\
\text { Tim }\end{array}$ & $\begin{array}{c}\text { Poin } \\
\text { Kemajuan } \\
\text { Siklus I }\end{array}$ & $\begin{array}{c}\text { Rata-rata } \\
\text { Tim } \\
\text { Siklus I }\end{array}$ & $\begin{array}{c}\text { Poin } \\
\text { Kemajuan } \\
\text { Siklus II }\end{array}$ & $\begin{array}{c}\text { Rata-rata } \\
\text { Tim } \\
\text { Siklus II }\end{array}$ & $\begin{array}{c}\text { Penghargaan } \\
\text { Tim }\end{array}$ \\
\hline 1 & $\mathrm{~K}$ & 20 & \multirow{5}{*}{20} & 20 & \multirow{5}{*}{20} & \multirow{5}{*}{ Tim Hebat } \\
\hline & S & 20 & & 20 & & \\
\hline & A & 20 & & 20 & & \\
\hline & $\mathrm{T}$ & 20 & & 20 & & \\
\hline & $P$ & 20 & & 20 & & \\
\hline \multirow[t]{5}{*}{2} & $\mathrm{~F}$ & 20 & \multirow{5}{*}{20} & 20 & \multirow{5}{*}{20} & \multirow{5}{*}{ Tim Hebat } \\
\hline & A & 20 & & 20 & & \\
\hline & $\mathrm{R}$ & 20 & & 20 & & \\
\hline & B & 20 & & 20 & & \\
\hline & $\mathrm{P}$ & 20 & & 20 & & \\
\hline \multirow[t]{2}{*}{3} & $\mathrm{~S}$ & 20 & & 20 & & \\
\hline & $\mathrm{D}$ & 30 & & 20 & & \\
\hline
\end{tabular}




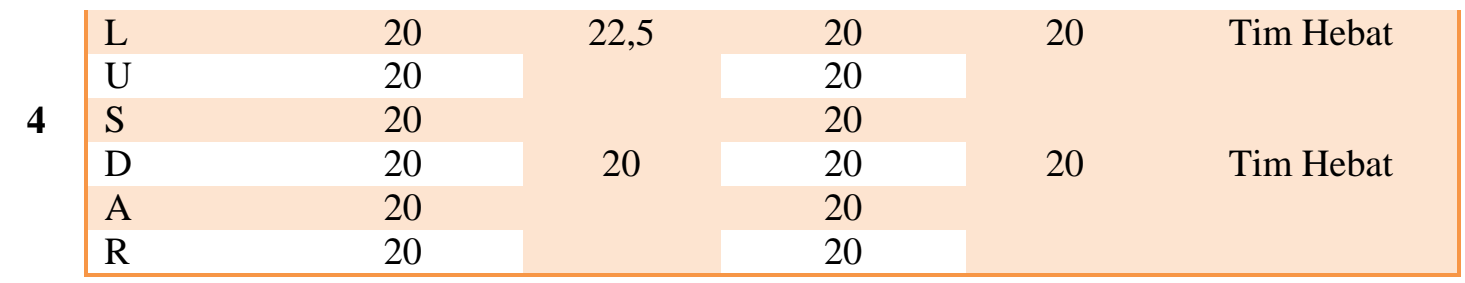

Sumber: Data Evaluasi Kuis Siklus I dan Siklus II (April 2013)

Tabel 2 menunjukkan hasil evaluasi kuis siklus I dengan siklus II. Terlihat adanya poin kemajuan setiap siklusnya. Ini mendandakan model pembelajaran Coperative Learning tipe STAD dan Snowball Throwing sesuai diterapkan dalam pembelajaran IPS kelas III. Walaupun terlihat dalam kelompok 3 untuk rata-rata poin kemajuan antara siklus I dan siklus II menurun sebesar 2,5. Pada siklus I rata-rata kemajuan tim adalah 22,5 kemudian menurun di siklus II menjadi 20. Ini dikarenakan salah satu dari anggota kelompok 3 dalam siklus II sedikit kurang enak badan, siswa tersebut terkena flu, sehingga dalam mengikuti kuis juga mengalamai kendala.

Ranah afektif dan psikomorik disini terlihat pada hasil lembar observasi keaktifan siswa. Melalui model pembelajaran Cooperative Learning tipe STAD dan Snowball Throwing berbasis bimbingan dengan berbantuan Media Massa dapat meningkatkan keaktivan dan prestasi belajar siswa. Lebih jelasnya dapat dilihat dalam tabel berikut ini.

Tabel 3 Keaktifan Belajar IPS Siklus I dan Siklus II

\begin{tabular}{|c|ccc|}
$\begin{array}{c}\text { Tahapan } \\
\text { Penelitian }\end{array}$ & Nilai & Kualifikasi & $\begin{array}{c}\text { Tingkat Keberhasilan } \\
\text { Pembelajaran }\end{array}$ \\
\hline Siklus I & $74,5 \%$ & Baik (B) & Berhasil \\
Siklus II & $77,5 \%$ & Baik (B) & Berhasil \\
\hline
\end{tabular}

Sumber: Data Observasi (April 2013)

Tabel 3 menunjukkan perbandingan rata-rata nilai keaktivan siswa dalam kelas baik siklus I ataupun siklus II. Pada siklus I rata-rata 74,5\% kemudian meningkat pada siklus II menjadi 77,5\%. Dalam siklus I masih ada siswa yang belum mengerti sepenuhnya mengenai STAD dan Snowball Throwing, sehingga keaktivan siswa berpengaruh. Tetapi dalam siklus II siswa sudah terbiasa menerapkan model tersebut, sehingga lebih dimengerti. Walaupun ada salah satu siswa yang terkena flu, sehingga konsentrasi menurun. Ini menunjukkan bahwa dengan penerapan model Cooperative Learning tipe STAD dan Snowball Throwing berbasis bimbingan berbantuan media massa dapat meningkatkan keaktivan siswa. Hal ini berarti relevan dengan penelitian yang dilakukan oleh Eko Budi Santoso (2011) menyatakan pembelajaran melalui model Cooperatif Learning tipe STAD dapat meningkatkan aktivitas dan hasil belajar pelajaran IPS siswa kelas II SDN Kemirisewu II Pasuruan. Hasil penelitian tersebut menunjukkan bahwa penerapan pembelajaran kooperatif tipe STAD dapat meningkatkan keaktifan dan prestasi belajar siswa.

Kemudian untuk ranah kognitif terlihat dengan adanya peningkatan tes hasil evaluasi yang selalu lebih baik. Untuk lebih jelasnya dapat dilihat pada tabel berikut.

Tabel 2 Prestasi Belajar IPS Siklus I dan Siklus II

\begin{tabular}{c|ccc|}
$\begin{array}{c}\text { Tahapan } \\
\text { Penelitian }\end{array}$ & Tidak Tuntas & Tuntas & Persentase \\
\hline Siklus I & 6 & 12 & $66 \%$ \\
Siklus II & 3 & 15 & $83,33 \%$ \\
\hline
\end{tabular}

Sumber: Data Tes Evaluasi Siklus I dan Siklus II (April 2013) 
Perbandingan hasil prestasi belajar di atas menunjukkan adanya peningkatan yang signifikan antara siklus I dan siklus II. Saat siklus I siswa yang tuntas 12 dengan persentase $66 \%$, kemudian saat siklus II naik menjadi yang tuntas 15 siswa dengan persentase $83,33 \%$. Dalam hal ini masih ada 3 siswa sampai siklus II tidak tuntas, ini dikarenakan 3 siswa tersebut dengan inisial DW dan RF siswa yang tergolong dalam kemampuan rendah. Saat diskusi kelompok, siswa tersebut mampu untuk berfikir kritis karena dibantu oleh teman-temannya dalam satu kelompok. Tapi saat mengerjakan tes evaluasi akhir per individu, mereka tidak bisa mengerjakan karena kemampuan yang terbatas.

Kecuali untuk siswa yang berinisial A saat siklus I siswa tersebut tuntas, tetapi saat siklus II siswa tersebut tidak tuntas. Siklus I dengan nilai 70 kemudian siklus II menurun menjadi 60. Ini dikarenakan siswa tersebut sakit, yaitu flu, sehingga konsentrasi menjadi berkurang dan gerak juga berkurang, tidak bisa optimal. Ketuntasan sebesar $83,33 \%$ dapat dinyatakan bahwa melalui penerapan model pembelajaran Cooperative Learning tipe STAD dan Snowball Throwing berbasis bimbingan berbantuan media massa dapat meningkatkan prestasi belajar siswa kelas III. Hal ini relevan dengan penelitian yang dilakukan oleh Agung Cipto Pratomo (2011) yang berjudul "Penerapan Metode Pembelajaran Kooperatif Snowball Drilling Untuk Meningkatkan Hasil Belajar Mata Pelajaran Sistem Pemindah Tenaga Kompetensi Memelihara Transmisi Kelas XI Teknik Kendaraan Ringan SMK Negeri 1 Gantiwarno, Klaten Tahun Ajaran 2010/2011" menunjukkan bahwa proses pembelajaran pada mata pelajaran sistem pemindah tenaga kompetensi memelihara transmisi menggunakan penerapan metode snowball drilling ini menunjukkan peningkatan hasil belajar siswa.

Hasil penelitian yang sudah dipaparkan diatas terbukti berhsail dikarenakan hipotesis terjawab, yaitu Penerapan Model Pembelajaran Cooperative Learning tipe STAD dan Snowball Drilling berbasis Bimbingan dan Berbantuan Media Massa dapat Meningkatkan Keaktifan dan Prestasi Belajar Siswa pada Mata Pelajaran IPS Kelas III Sekolah Dasar di Gugus Wibisono Kecamatan Jati Kabupaten Kudus dengan indikator keberhasilan yang terpenuhi semua, yaitu.

1. Prestasi belajar IPS siswa pada mata pelajaran IPS minimal 65 dengan ketuntasan belajar klasikal $75 \%$.

2. Keaktifan siswa dalam pembelajaran IPS menggunakan model pembelajaran Model Pembelajaran Cooperative Learning Tipe STAD Dan Snowball Throwing Berbasis Bimbingan dan Berbantuan Media Massa sebesar $\geq 65$ dengan kriteria sekurangkurangnya baik.

\section{SIMPULAN}

Simpulan dari penelitian ini adalah penerapan model pembelajaran cooperative learning tipe STAD dan Snowball Drilling berbasis bimbingan dan berbantuan media massa dapat meningkatkan keaktifan dan prestasi belajar siswa pada mata pelajaran IPS pada siswa kelas III SD Tumpangkrasak 2 Kecamatan Jati Kabupaten Kudus.

\section{DAFTAR PUSTAKA}

Arikunto, Suharsimi. 1996. Penelitian Tindakan Kelas. Jakarta:Bumi Aksara

Arikunto, Suharsimi. 2006. Prosedur Penelitian Suatu Pendekatan Praktik. Jakarta: PT. Rineka Cipta. 
Bogdan, R.C dan Taylor, S. 1993. Kualitatif (Dasar-dasar Penelitian) (terjemahan), Surabaya; Usaha Nasional.

Depdikbud. 1999. Bahan Pelatihan : Penelitian Tindakan Kelas (Action Research). Departemen Pendidikan dan Kebudayaan. Direktorat Jenderal Pendidikan Dasar dan Menengah.

Depdiknas. (2006). Pedoman Memilih dan Menyusun Bahan Ajar. Jakarta: Direktorat Jenderal Pendidikan Dasar dan Menengah.

Djamarah,Syaiful Bachri. 2011. Psikologi Belajar. Jakarta: Rineka Cipta

Eko Budi, Santoso. 2011. Penerapan model pembelajaran Cooperative Learning tipe STAD untuk meningkatkan aktivitas dan hasil belajar tematik pada siswa kelas II SDN Kemirisewu II Pasuruan. Skripsi. Malang: Universitas Negeri Malang

Furchan, Arif, 2004. Pengantar Penelitian Dalam Pendidikan. Surabaya: Usaha Nasional

Hamalik, Oemar. 2003. Perencanaan Pengajaran Berdasarkan Pendekatan Sistem, cetakan kedua. Jakarta: PT. Bumi Aksara

2008. Proses Belajar Mengajar. Jakarta: Bumi Aksara

Muhibbin, S. 1995. Psikologi Pendidikan: Suatu Pendekatan Baru. Bandung: Remaja Rosdakarya.

Kunandar, 2008. Langkah Mudah Penelitian Tindakan Kelas, Jakarta: Rajawali Pers

Lie, Anita. 2007. Cooperative Learning. Jakarta: Grasindo

Muslich, Masnur. 2007. KTSP (Kurikulum Tingkat Satuan Pendidikan) Dasar Pemahaman dan Pengembangan. Jakarta: Bumi Aksara.

Roestiyah N.K. 1991. Srategi Belajar Mengajar, Cetakan ke-4. Jakarta: Bina Aksara.

Slameto. 1995. Evaluasi Pendidikan. Jakarta: PT. Bumi Aksara.

Slavin, Robert E. 2010. Cooperative Learning. Maryland: John Hopkins.

Solihatin, Solihatin. 2008. Cooperative Learning Analisis Model Pembelajaran IPS SD. Jakarta: Bumi Aksara.

Stahl, Robert J. 1994. Cooperative Learning in Sosial Studies: Hand Book for Teachers. USA: Kane Publishing Service, Inc.

Sukiman. Dkk. 2013. Penerapan Model Pembelajaran Cooperatif Tipe STAD dan Snowball Drilling Berbasis Bimbingan dan Berbantu Media Massa Untuk Meningkatkan Keaktifan dan Prestasi Belajar Siswa Pada Mata Pelajaran IPS. Penelitian. Kudus: Universitas Muria Kudus 
Tim Penyusun Kamus Pusat Bahasa. 2002. Kamus Besar Bahasa Indonesia, edisi 3. Cetakan 2. Jakarta: Balai Pustaka.

Tim Pustaka Yustisia. 2007. Panduan Lengkap KTSP (Kurikulum Tingkat Satuan Pendidikan) SD/MI, SMP/MTs, dan SMA/SMK. Yogyakarta: Pustaka Yustisia.

Undang-Undang tentang Sistem Pendidikan Nasional No. 20 tahun 2003 Winkel, W.S. 1996. Psikologi Pengajaran. Jakarta: PT. Gramedia. 